Article

\title{
Removal of Zinc Ions Using Hydroxyapatite and Study of Ultrasound Behavior of Aqueous Media
}

\author{
Simona Liliana Iconaru ${ }^{1}$, Mikael Motelica-Heino ${ }^{2}$, Régis Guegan ${ }^{3}$, Mihai Valentin Predoi ${ }^{4}$, \\ Alina Mihaela Prodan ${ }^{5,6}$ and Daniela Predoi ${ }^{1, *}$ \\ 1 National Institute of Materials Physics, Atomistilor Street, No. 405A, P.O. Box MG 07, Magurele 077125, \\ Romania; simonaiconaru@gmail.com \\ 2 Institut des Sciences de la Terre d'Orléans (ISTO), UMR 7327 CNRS Université d'Orléans, \\ 1A rue de la Férollerie, 45071 Orléans CEDEX 2, France; mikael.motelica@univ-orleans.fr \\ 3 Faculty of Science and Engineering, Global Center for Science and Engineering, Waseda University, 3-4-1, \\ Okubo, Shinjuku-ku, Tokyo 169-8555, Japan; regis.guegan@aoni.waseda.jp \\ 4 Department of Mechanics, University Politehnica of Bucharest, BN 002, 313 Splaiul Independentei, Sector 6, \\ Bucharest 060042, Romania; predoi@gmail.com \\ 5 Emergency Hospital Floreasca Bucharest, 8 Calea Floreasca, Sector 1, Bucharest 014461, Romania; \\ prodan1084@gmail.com \\ 6 Carol Davila University of Medicine and Pharmacy, 8 Eroii Sanitari, Sector 5, Bucharest 050474, Romania \\ * Correspondence: dpredoi@gmail.com; Tel.: +40-212418154
}

Received: 6 June 2018; Accepted: 1 August 2018; Published: 3 August 2018

\begin{abstract}
The present study demonstrates the effectiveness of hydroxyapatite nanopowders in the adsorption of zinc in aqueous solutions. The synthesized hydroxyapatites before (HAp) and after the adsorption of zinc (at a concentration of $50 \mathrm{mg} / \mathrm{L}$ ) in solution (HApD) were characterized using X-ray diffraction (XRD), and scanning and transmission electron microscopy (SEM and TEM, respectively). The effectiveness of hydroxyapatite nanopowders in the adsorption of zinc in aqueous solutions was stressed out through ultrasonic measurements. Both Langmuir and Freundlich models properly fitted on a wide range of concentration the equilibrium adsorption isotherms, allowing us to precisely quantify the affinity of zinc to hydroxyapatite nanopowders and to probe the efficacy of hydroxyapatite in removal of zinc ions from aqueous solutions in ultrasonic conditions.
\end{abstract}

Keywords: hydroxyapatite; ultrasonic measurements; water depollution; zinc; adsorption

\section{Introduction}

The most pressing issue today is the increase in contaminated sites in both numbers and area as a result of rapidly growing industrial activities that have led to ecosystem damage due to excessive pollution. Moreover, many industries have the potential to pollute water resources with different wastes such as organic and inorganic compounds. The most frequent pollutants due to the industrial sites are heavy metal ions and aromatic compounds [1,2]. Due to an increased awareness regarding the well-being of the planet, tremendous attention has been paid to heavy metals such as cadmium, lead, zinc, and arsenic, which are reported to have a detrimental impact on the environment all over the world. These particular heavy metals are not biodegradable and can be accumulated in organisms, thus representing a serious health threat to plants, animals and human beings. Indeed, metals, such as zinc, cadmium, led, and arsenic, show a high toxicity even at low concentrations. Even though human do not have direct contact with these pollutants, human health can be indirectly influenced by multiple ways, particularly through drinking water and the food chain. In addition, in agriculture, the presence of heavy metals pollution in soils can cause great harm to crop growth, yield and quality. Therefore, the removal of heavy metals, from natural waters or soils, has attracted considerable attention $[3,4]$. 
Various conventional technologies for the removal of heavy metal ions from aqueous solution, such as chemical precipitation, electrochemical treatment, ion exchange, reverse osmosis and electrodialysis, have been described [5]. Recently, considerable attention has been given to alternative methods, one of the most promising being the use of cheap materials as potential sorbents for heavy metals removal [6-8]. The most popular materials used as sorbents have been carbons, zeolites, clays, biomass and polymeric materials [9]. However, in the literature, it has been reported that these materials exhibit low adsorption capacities towards heavy metals ions and suffers from separation inconvenience. Therefore, considerable efforts are still needed for the development of newly materials that can be used as adsorbents in decontamination applications. Several studies conducted in recent years have reported the applications of mineral materials in the disposal of wastewaters contaminated with heavy metals [9].

Materials such as zeolite [10], clay minerals [11,12] and other organo-derived clay materials [13-15] have been reported to be promising candidates in the treatment of wastewater due to their excellent surface characteristics. Recent studies have reported that phosphate minerals represent promising materials in the treatment of wastewaters for the removal of fluoride and heavy metals $[16,17]$. Incentive results on the efficacy of phosphate minerals have been reported for the activity of hydroxyapatite (HAp) with the chemical formula $\mathrm{Ca}_{10}\left(\mathrm{PO}_{4}\right)_{6}(\mathrm{OH})_{2}$ as an excellent material for removing long-term pollutants from contaminated water due to its high affinity for heavy metals, low water solubility, high stability and low cost [18].

One of the most popular and widely used adsorbents in water treatment especially for heavy metal removal has been activated carbon since it was introduced [19]. Even though activated carbon [20], silica gel [21] and activated alumina [22] are highly effective for the adsorption of heavy metals from water, their use is restricted, as these materials remain expensive materials. Therefore, they cannot be widely used in small-scale industries because of cost inefficiency. Recently, the interest in the research of alternative adsorbents to replace the costly activated carbon, silica gel and activated alumina has increased. Considerable attention has been focused on adsorbents, with metal-binding capacities and able to remove heavy metals from contaminated water at low cost $[23,24]$. Natural materials such as chitosan, zeolites, chitosan, clay, or waste products from industrial operations such as fly ash, coal, and oxides have been classified as low-cost adsorbents [25]. It was estimated that chitosan could be obtained using fish and crustaceans as raw materials at a market price of US\$15.43/ $\mathrm{kg}$ [26]. Similar estimations have been made regarding the price of zeolites which are considered very cheap (about US\$ 0.03-0.12/kg) [27]. On the other hand, apatite materials have been depicted as ideal materials for long-term containment of pollutants due to their high sorption capacity for actinides and heavy metals [28], low water solubility [29], high stability under reducing and oxidizing conditions, availability and low cost [30]. Moreover, natural hydroxyapatite obtained from bovine cortical bone ash [30] has been considered as an environmentally benign functional material and has been widely investigated for water treatment applications due to its high capacity for the removal of heavy metal ions, low water solubility, high stability under reducing and oxidizing conditions, availability and low cost [31-33].

Zinc is considered one of the most important elements and plays an essential role in biological functions. Nevertheless, zinc ions at a certain concentration display a great toxicity towards human organism [34]. Thus, the Canadian Water Quality Guidelines [35] and WHO [36] defined that the maximum admissible level of zinc in drinking water be $\leq 5 \mathrm{mg} / \mathrm{L}$. The contamination of zinc in effluents often results from industry discharges. Since zinc is not biodegradable, it travels through food chain via bioaccumulation and possess a high toxicity risk to humans [37]. In the last years, the use of ultrasound measurements to characterize suspensions has become a large and growing application, as reviewed by McClements [38]. Several studies have stated that ultrasonic measurements could offer significant insight about materials properties $[39,40]$. Even though there have been reported only a handful of few basic and quantitative investigations, the common conclusion of the reported papers has been that ultrasound methods are very rigorous and much less sensitive to contamination 
providing accurate information about the microstructural properties as well as deformation processes of the investigated samples [41,42].

In this context, this study focused on using hydroxyapatite nanopowders for the removal of zinc ions from contaminated waters. It principally aimed at pointing out the interests of hydroxyapatites as potential adsorbents for zinc $\left(\mathrm{Zn}^{2+}\right)$ in aqueous solution. Pure hydroxyapatite obtained by an adapted coprecipitated method was characterized by XRD, SEM and TEM before and after removing zinc from aqueous solutions. Adsorption kinetics of zinc ions $\left(\mathrm{Zn}^{2+}\right)$ on hydroxyapatite was studied by the Langmuir and Freundlich models. The effectiveness of decontamination was correlated with ultrasonic measurements. The advantages of ultrasonic techniques are synthetically presented in the book of Povey [43] and an updated review was presented by Povey [44]. More recently, Galaz [45] presented an experimental verification of ultrasonic methods applied to suspensions of small particles. There are even ultrasonic studies dedicated to the estimation of the suspension particle sizes, from which we mention here on of the most recent [46]. In this paper, the ultrasonic technique is simple and directly applicable, based on acoustic signature of the signal in different suspensions. The only limitation is that the reference fluid and the depolluted suspension must be tested with the same experimental setup.

\section{Experimental Section}

\subsection{Synthesis of Hydroxyapatite Nanoparticles (HAp)}

The hydroxyapatite, $\mathrm{Ca}_{10}\left(\mathrm{PO}_{4}\right)_{6}(\mathrm{OH})_{2}$, nanopowders were obtained using a previously described adapted coprecipitation method [47,48]. The molar ratio Ca:P was maintained at 1.67 [36].

\subsection{Structural and Morphological Characterizations}

The structure and morphology of the recovered powders were characterized by XRD, SEM and TEM.

X-ray diffraction was performed for HAp nanopowders before and after zinc ions adsorption from aqueous solution using a Bruker D8 Advance diffractometer (Bruker, Karlsruhe, Germany) with nickel filtered $\mathrm{CuK} \alpha(\lambda=1.5418 \AA)$ radiation and a high efficiency one-dimensional detector (Lynx Eye type, Bruker, Karlsruhe, Germany) operated in integration mode. The data were collected over the $2 \theta$ range of $25-55^{\circ}$, using a step size of $0.02^{\circ}$ and 34 s measuring time per step.

The morphology of the HAp nanopowders before and after zinc ions adsorption from aqueous solution was investigated by scanning electron microscopy (SEM) using a HITACHI S4500 microscope (Hitachi High Technologies America, Inc., Schaumburg, IL, USA).

The size and morphology of HAp nanopowders before and after zinc ions adsorption from aqueous solution were analyzed by transmission electron microscopy (TEM) using a CM 20 (Philips-FEI, Eindhoven, The Netherlands), equipped with a filament Lab6 that works at $200 \mathrm{kV}$. For TEM investigations, the nanopowders were dispersed in ethanol using an ultrasonic bath (Retsch $\mathrm{GmbH}$, Haan, Germany) and a drop of the resulting solution was deposited on a carbon-coated Cu grid.

\subsection{Batch Adsorption Experiments}

The effectiveness of zinc adsorption onto hydroxyapatite nanopowders was investigated by batch adsorption experiments. The experiments were conducted in $40 \mathrm{~mL}$ silicon tubes with aqueous solutions containing zinc ions in a concentration range of 5-150 $\mathrm{mg} \mathrm{L}^{-1}$. The amount of the HAp nanopowder used as adsorbent was $0.2 \mathrm{~g}$ and the solution $\mathrm{pH}$ was adjusted to 5 with a $0.1 \mathrm{M}$ hydrochloric acid $(\mathrm{HCl})$ solution. During the experiments, the solution volume was kept at $20 \mathrm{~mL}$ and the mixture was stirred using a Mixer SRT1 Roller (Stuart Scientific, Staffordshire, UK) for $24 \mathrm{~h}$. After $24 \mathrm{~h}$, the tubes were centrifuged for $1 \mathrm{~h}$ at 10,000 rpm. The supernatant was filtered, recovered and analyzed by Atomic Absorption Spectrometry (AAS) [49]. The batch experiments were carried out at room temperature, in triplicate. The AAS measurements were performed using a $213.9 \mathrm{~nm}$ wavelength for zinc. 


\subsection{Ultrasonic Measurements}

Ultrasonic measurements were performed on water $(\mathrm{Wi})$, water contaminated with zinc (50 mg/L zinc ions) (WZn) and water after decontamination (Wd). Solutions analyzed by ultrasonic measurements, water (Wi), zinc contaminated water (50 mg/L zinc ions) (WZn) and water after decontamination $(\mathrm{Wd})$ were placed in the thermally controlled container. The temperature of the solutions was kept constant at $21^{\circ} \mathrm{C}$. During the measurements, the WZn and Wd samples were stable and no precipitation of nanoparticles was observed at the end of the experiment. The chain of measurement used to ultrasonic characterization of Wi, WZn, and Wd is shown in Figure 1.

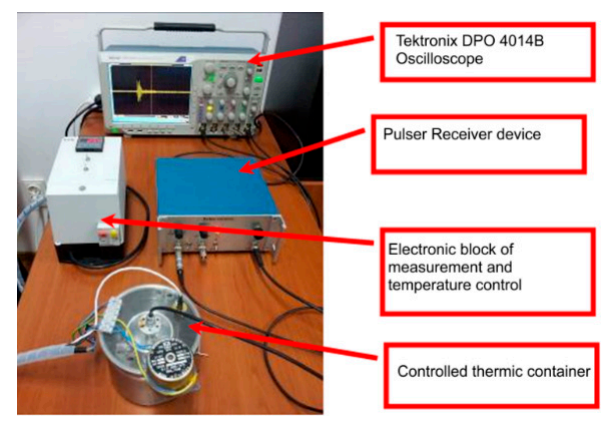

Figure 1. Overview of the chain of measurement.

\section{Results and Discussions}

To highlight the effectiveness of hydroxyapatite in the removal of zinc ions from aqueous solutions, XRD, SEM, EDX and TEM analysis were performed on prepared hydroxyapatite (HAp) and hydroxyapatite recovered after adsorption of zinc ions from aqueous solutions (HApD). Figure 2a shows the XRD patterns of the HAp and HApD after zinc adsorption from aqueous solutions containing zinc ions in a concentration of $50 \mathrm{mg} / \mathrm{L}$. The XRD peaks from X-ray diffraction patterns of prepared HAp and HApD corresponds to the standard XRD peaks of hexagonal hydroxyapatite (JCPDS 9-432). XRD analysis did not reveal other calcium phosphate phases or mineral formation in the solid of $\mathrm{Zn}$ reaction with phosphate in agreement with previous studies conducted by Cao et al. [50]. The crystal size was determined based on Scherer's formula $(D=0.9 \lambda / \beta \cos \theta)$. In Scherer's formula, $\lambda$ is the wave length of X-rays, $\beta$ is full width at half height of peak in radians and $\theta$ is the angle of diffraction. To estimate the mean crystallite size (D) of the HAp and HApD samples, the line broadening of the peaks at $2 \theta=25.8^{\circ}$ assigned to the crystalline plane (002) was used. The crystal size of HAp determined using the Scherer's formula was $18.8 \pm 1 \mathrm{~nm}$. The D value of the HApD was $15.12 \pm 1 \mathrm{~nm}$. The characteristic diffraction peaks such as (002), (210), (211), (300), (202), (310), (222), (213), and (004) can be clearly seen, indicating the formation of HAp crystalline phase. The XRD patterns of HApD showed a similar curve. We observed that the peak associated to (002) diffraction of the HApD shifted toward the high diffraction angle (Figure 2b). According to Hayakawa et al. [51], this behavior suggested that the $\mathrm{Zn}^{2+}$ ions were substituted for the $\mathrm{Ca}^{2+}$ ion.

SEM images of the HAp powders before and after zinc adsorption from aqueous solutions containing zinc ions in a concentration of $50 \mathrm{mg} / \mathrm{L}$ are presented in Figure 3a,b. The SEM images revealed that all investigated samples presented nanoparticles with elongated morphology and a tendency of forming agglomerates due to their nanometric size. Furthermore, SEM images suggested that the morphology of the samples was slightly influenced by the presence of the zinc ions in the powders.

In the EDX spectra of Hap, the presence of peaks for $\mathrm{Ca}, \mathrm{P}$ and $\mathrm{O}$, the major constituent elements of hydroxyapatite, have been highlighted (Figure 4a). In addition to HAp's constituents, the EDX spectrum of HApD reveals the presence of zinc (Figure $4 b$ ). By the presence of the maxima attributed to zinc in the EDX spectrum of HApD, we can conclude that zinc ions were efficiently adsorbed by synthetized HAp. 

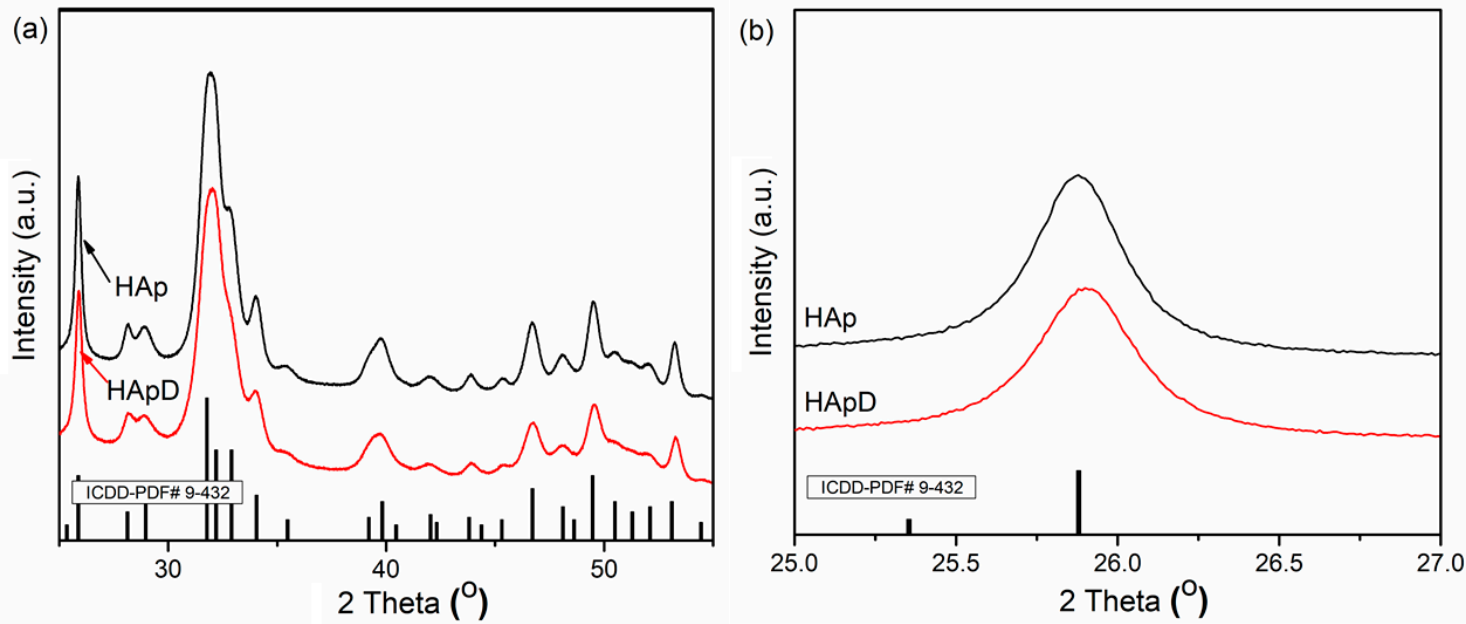

Figure 2. XRD patterns of hydroxyapatite (HAp) and hydroxyapatite recovered after zinc adsorption from aqueous solutions (HApD) containing concentration of $50 \mathrm{mg} / \mathrm{L}$ zinc ions. (a) $2 \theta$ range of $25-55^{\circ}$; (b) $2 \theta$ range of $25-27^{\circ}$.
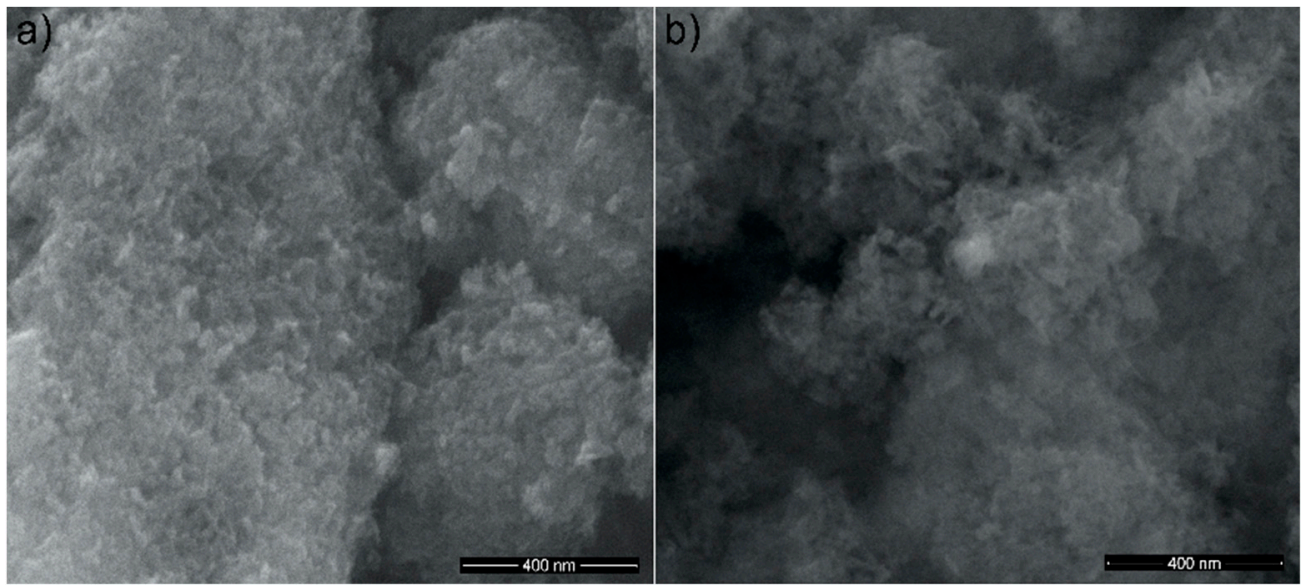

Figure 3. SEM images of HAp (a); and hydroxyapatite recovered after zinc adsorption from aqueous solutions (HApD) containing concentration of $50 \mathrm{mg} / \mathrm{L}$ zinc ions (b).
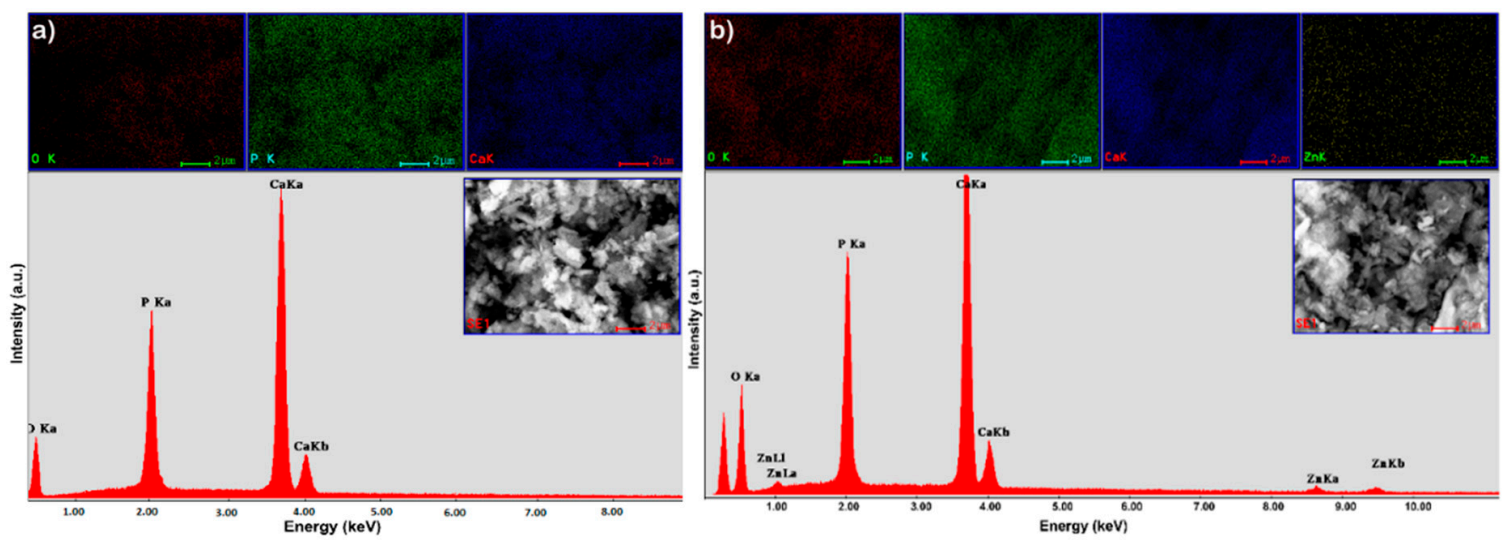

Figure 4. EDX spectrum and elemental mapping of synthetized HAp (a); and EDX spectrum and elemental mapping of hydroxyapatite recovered after zinc adsorption from aqueous solutions (HApD) containing concentration of $50 \mathrm{mg} / \mathrm{L}$ zinc ions (b). 
In addition, the elemental mapping of HAp and HApD, as shown in Figures 4 and 5, provided information about the homogeneity of the samples and the uniform distribution of the $\mathrm{Ca}, \mathrm{P}$ and $\mathrm{O}$. The uniform distribution of $\mathrm{Zn}$ was also observed in HApD. These results were fully consistent with X-ray diffraction analysis.

Figure 5 presents the transmission electron micrographs of pure hydroxyapatite (HAp) and hydroxyapatite recovered after zinc adsorption from aqueous solutions (HApD) containing zinc ions in a concentration of $50 \mathrm{mg} / \mathrm{L}$. The average particle size of the pure HAp was $20 \pm 1 \mathrm{~nm}$. The average particle size of the HApD decreased to $17 \pm 1 \mathrm{~nm}$, in agreement with the X-ray results. The particles are less elongated. Furthermore, it should be noted that more agglomeration of the particles after $\mathrm{Zn}$ ion adsorption was observed. The particle size and morphology changed little after zinc adsorption from aqueous solutions containing $50 \mathrm{mg} / \mathrm{L}$ zinc ions.
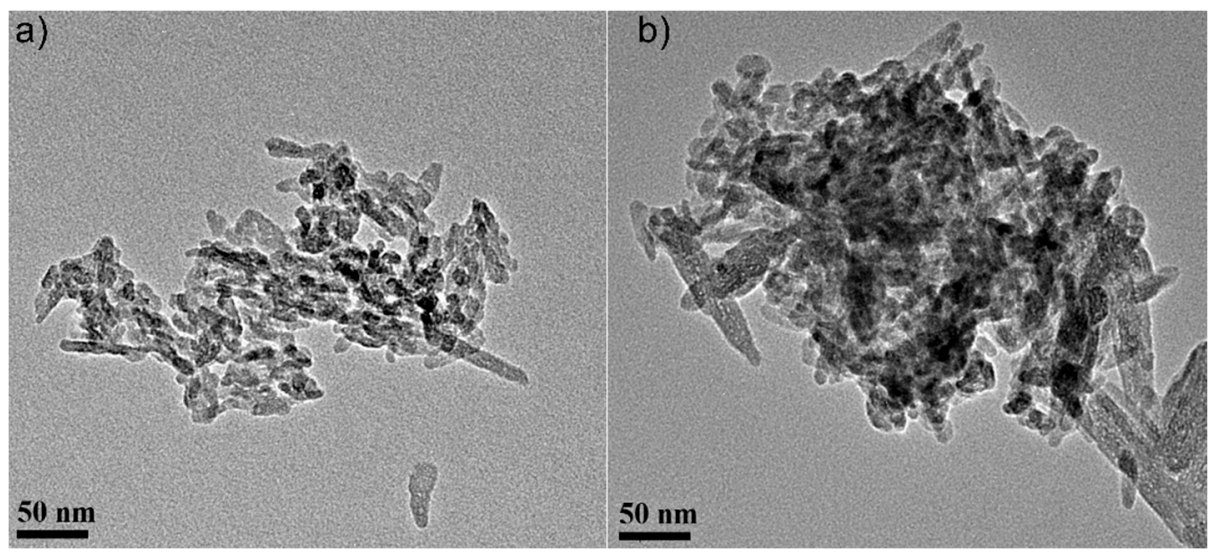

Figure 5. Transmission electron microscopy (TEM) micrographs of the HAp powders before (a) and after zinc adsorption from aqueous solutions containing zinc ions (HApD) in a concentration of $50 \mathrm{mg} / \mathrm{L}$ (b). Scale bar: $50 \mathrm{~nm}$.

The adsorption data obtained from the batch equilibrium experiments were used in the kinetic studies and the applicability of different adsorption isotherms to $\mathrm{Zn}^{2+}$ were studied. The percentage removal efficiency of the adsorbents $\mathrm{R}(\%)$ and the sorption capacity at equilibrium were calculated using the following Equations (1) and (2):

$$
\begin{gathered}
\mathrm{R}(\%)=\frac{\mathrm{C}_{0}-\mathrm{C}_{\mathrm{e}}}{\mathrm{C}_{0}} \times 100 \\
\mathrm{q}_{\mathrm{e}}=\left(\mathrm{C}_{0}-\mathrm{C}_{\mathrm{e}}\right) \times \frac{\mathrm{V}}{\mathrm{m}}
\end{gathered}
$$

where $\mathrm{C}_{0}(\mathrm{mg} / \mathrm{L})$ is the initial metal ion concentration, $\mathrm{C}_{\mathrm{e}}(\mathrm{mg} / \mathrm{L})$ is the equilibrium concentration of $\mathrm{Zn}(\mathrm{II}), \mathrm{V}(\mathrm{L})$ is the volume of the solution and $\mathrm{m}(\mathrm{g})$ is the mass of the adsorbent.

The adsorption of zinc ions from aqueous solutions using HAp nanopowders was studied in batch experiments and the removal efficiency of adsorption of zinc ions from aqueous solution by HAp is presented in Figure 6. The initial zinc ions concentration was set in the range of 5-150 mg/L. In Figure 6, the adsorption capacity increases with the increase of the initial zinc ions concentration. By increasing the initial concentration of zinc, the interaction between adsorbent and zinc ions is enhanced, leading to an increase in the adsorption uptake of zinc ions onto HAp nanopowders. Figure 6 shows that the percentage zinc ions removal increased from $30.88 \%$ to $41.57 \%$ with the increase of the initial zinc concentration from $5 \mathrm{mg} / \mathrm{L}$ to $150 \mathrm{mg} / \mathrm{L}$. It was also noticed that, after the concentration of $110 \mathrm{mg} / \mathrm{L}$, the removal percentage stabilized around the value of $40 \%$. 


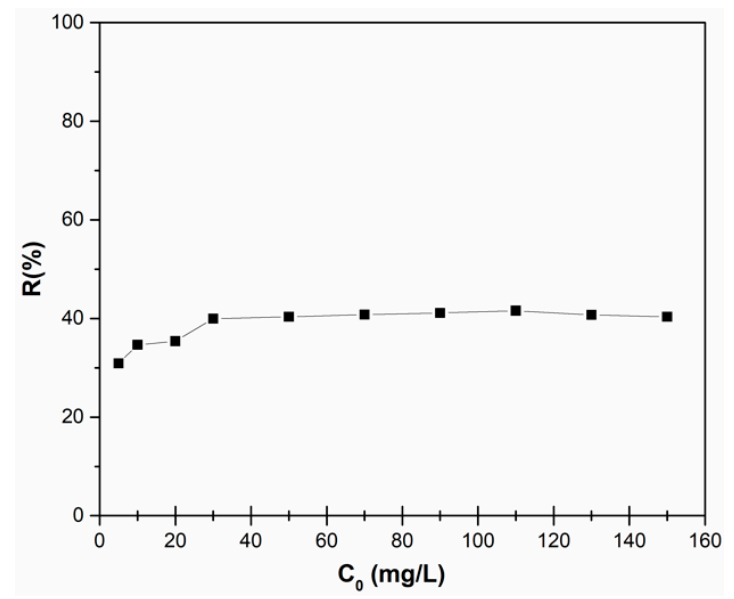

Figure 6. Removal efficiency of zinc ions on HAp depending on the initial zinc concentration.

The values corresponding to the percentage of zinc ions removal and the adsorption capacity as a function of zinc concentrations at equilibrium are presented in Table 1. The results show that the adsorption capacity of HAp nanopowders increases with the increase of the zinc initial concentration.

Table 1. The percentage of zinc ions removal and adsorption capacity of HAp upon varying the zinc concentrations.

\begin{tabular}{ccc}
\hline Zinc Concentration $(\mathbf{m g} / \mathbf{L})$ & \% Removal of Zinc Ions & Adsorption Capacity qe (mg/g) \\
\hline 10 & 34.65 & 3.47 \\
20 & 35.4 & 7.08 \\
30 & 39.97 & 11.99 \\
50 & 40.36 & 20.18 \\
70 & 40.77 & 28.54 \\
\hline
\end{tabular}

The equilibrium interactions between adsorbent and adsorbate are usually described with the aid of sorption isotherms [52]. The experimental data obtained from the batch equilibrium experiments were fitted using Langmuir and Freundlich isotherm equations. Langmuir isotherm is generally constructed with the assumption that a fixed number of adsorption sites are available and that the adsorption is reversible; therefore, this model can be used only when the adsorbent surface is homogeneous. The Langmuir isotherm is expressed as described by Langmuir [53]:

$$
\frac{C_{e}}{q_{e}}=\frac{C_{e}}{q_{m}}+\frac{1}{K_{L} \times q_{m}}
$$

where $C_{e}$ is the equilibrium concentration of heavy metal ions $(\mathrm{mg} / \mathrm{L}), \mathrm{q}_{\mathrm{e}}$ is the equilibrium adsorption uptake of heavy metal ions $(\mathrm{mg} / \mathrm{g}), \mathrm{q}_{\mathrm{m}}$ is the amount adsorbed to form a complete monolayer on the surface $(\mathrm{mg} / \mathrm{g})$ and $\mathrm{K}_{\mathrm{L}}$ is the Langmuir constant $(\mathrm{L} / \mathrm{mg})$.

Meanwhile, the Freundlich model is based on the assumption that the adsorption takes place on a heterogeneous surface. The Freundlich isotherm is describe by the following equation [54]:

$$
\ln q_{e}=\ln K_{F}+\frac{\frac{1}{n}}{\ln C_{e}}
$$

where $\mathrm{q}_{\mathrm{e}}$ is the amount that was adsorbed at the equilibrium concentration $(\mathrm{mg} / \mathrm{g}), \mathrm{K}_{\mathrm{F}}$ is an empirical constant of Freundlich isotherm $(\mathrm{L} / \mathrm{mg}), \mathrm{C}_{\mathrm{e}}$ is the equilibrium concentration of zinc ions in solution $(\mathrm{mg} / \mathrm{L})$ and $\mathrm{n}$ is a parameter correlated with the intensity of adsorption. 
For a better understanding of the adsorption capacity of HAp nanopowders, the equilibrium adsorption isotherm for zinc ions onto HAp at room temperature is presented in Figure 7. Figure 7 shows the adsorption capacity of zinc ions upon varying the zinc ions concentration in the aqueous solutions.

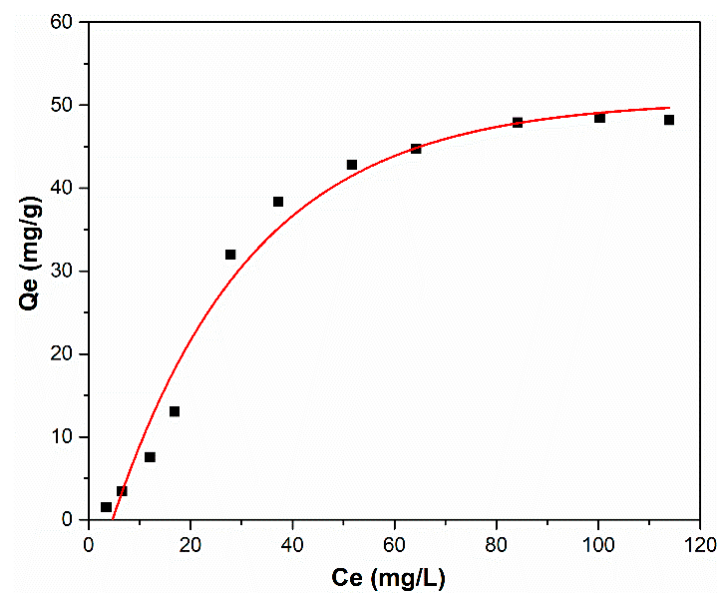

Figure 7. Equilibrium adsorption isotherm for zinc ions onto HAp at room temperature.

The Langmuir and Freundlich linearized fits for the adsorption of zinc ions on HAp are shown in Figure 8. The constants calculated from the linearized plots are reported in Table 2.
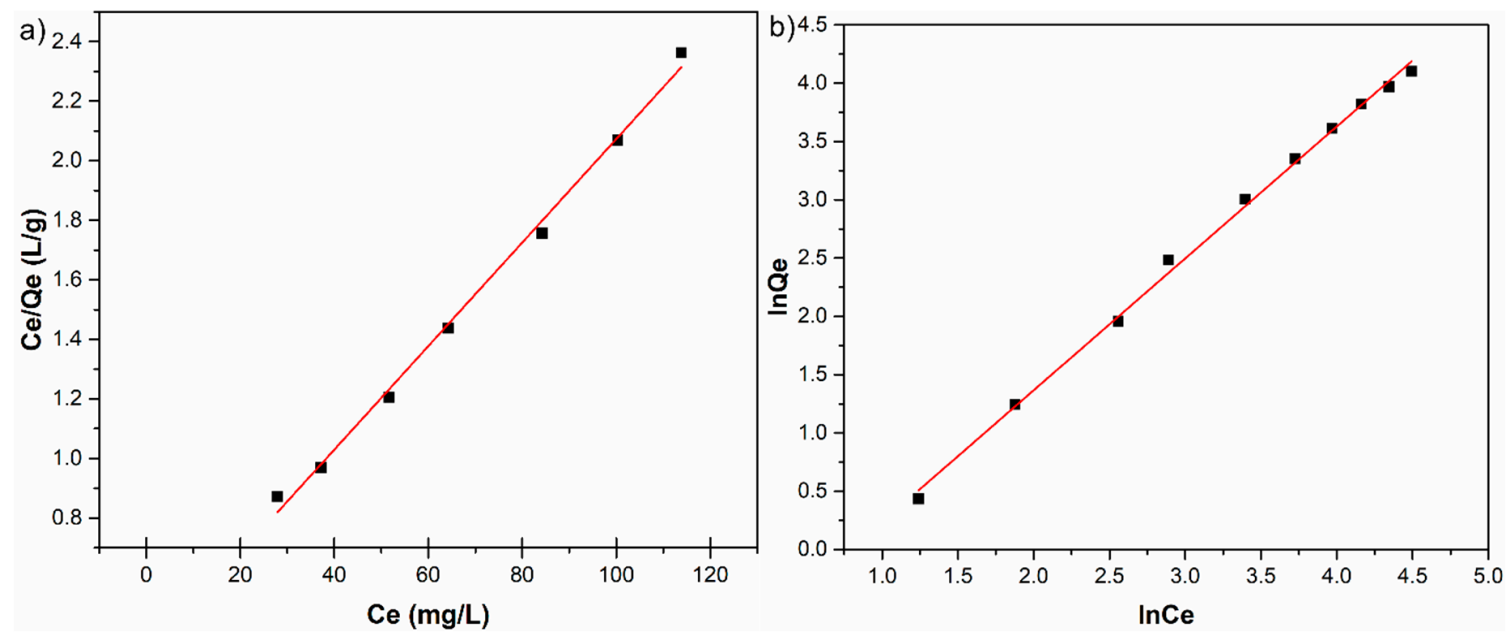

Figure 8. Langmuir (a); and Freundlich (b) linearized fits for the adsorption of zinc ions on HAp.

Table 2. Isotherms parameters for zinc adsorption onto HAp.

\begin{tabular}{cccccccc}
\hline \multirow{2}{*}{ Pollutant } & \multirow{2}{*}{ Sample } & \multicolumn{3}{c}{ Langmuir } & \multicolumn{3}{c}{ Freundlich } \\
\cline { 3 - 8 } & & $\mathbf{q}_{\mathbf{m}}(\mathbf{m g} / \mathbf{g})$ & $\mathbf{K}_{\mathbf{L}}(\mathbf{L} / \mathbf{m g})$ & $\mathbf{R}^{\mathbf{2}}$ & $\mathbf{N}$ & $\mathbf{K}_{\mathbf{F}}$ & $\mathbf{R}^{\mathbf{2}}$ \\
\hline $\mathrm{Zn}^{2+}$ & HAp & 57.504 & 0.052 & 0.995 & 0.884 & 0.408 & 0.997 \\
\hline
\end{tabular}

At room temperature, the correlation coefficient of Freundlich isotherm for $\mathrm{Zn}^{2+}$ removal by HAp was 0.997 and had a higher value than the correlation coefficient of Langmuir isotherm, which was 0.995. On the other hand, the maximum adsorption capacity for the solid phase calculated from the linearized form of Langmuir equation, $\mathrm{q}_{\mathrm{m}}$, for $\mathrm{Zn}^{2+}$ was $57.504 \mathrm{mg} / \mathrm{g}$ and the Langmuir constant $\mathrm{K}_{\mathrm{L}}$ 
for the adsorption of $\mathrm{Zn}^{2+}$ was $0.052 \mathrm{~L} / \mathrm{mg}$. The linear plot of $\mathrm{C}_{e} / \mathrm{Q}_{\mathrm{e}}$ against $\mathrm{C}_{\mathrm{e}}$ for the adsorption of zinc ions on HAp exhibited in Figure 8a revealed that the adsorption is in good agreement with the Langmuir model.

By fitting the data using the Freundlich adsorption isotherm model, a linear relationship was obtained where $\mathrm{K}_{\mathrm{F}}$ has been equal to 0.408 , and the $1 / \mathrm{n}$ was equal to 1.13 (Figure $8 \mathrm{~b}$ ). Following these results, the inverse of the empirical parameter related to the intensity of adsorption has values greater than $1(1 / \mathrm{n}>1)$ which shows that the absorption coefficient increases with increase in concentration resulted as effect of increase in hydrophobic surface characteristics after monolayer. The results suggest that HAp nanopowders exhibited a good affinity towards zinc ions, rendering HAp a suitable promising adsorbent for water treatment technologies.

For the first time, the effectiveness of hydroxyapatite in water decontamination was highlighted by ultrasonic studies on water (Wi), zinc-contaminated water (50 mg/L zinc ions) (WZn) and water after decontamination $(\mathrm{Wd})$. The parameters confirming the decontamination are the signal velocity in the suspension and the similarity of the acoustic signals of decontaminated water and pure water. For the interpretation of the ultrasonic signals, specialized programs have been used, able to provide essential information on the parameters characteristic of each studied material. For the ultrasonic characterization of the dispersions presented above (Wi, HZ2 and Wf) it was considered that the propagation velocity of the acoustic waves in homogeneous liquids can be calculated with the relation:

$$
c=\sqrt{\frac{1}{\kappa \rho}}
$$

where the adiabatic compressibility $\kappa$ is the inverse of the compression elastic modulus $(K=1 / \kappa)$. The ultrasound velocity through solutions and suspensions, in the linear approximation of small disturbances, depends on the average density and average compressibility. These averaged values are calculated from the Urick equations [55]:

$$
\kappa=\sum_{i} \Phi_{i} \kappa_{i} ; \quad \rho=\sum_{i} \Phi_{i} \rho_{i}
$$

in which $\Phi_{i}$ represents the volumetric fraction of component of index $i$. The volumetric fraction can be transformed into mass fraction by:

$$
w=\frac{\Phi \rho_{2}}{\Phi \rho_{2}+(1-\Phi) \rho_{1}}
$$

in thecase of two phases, marked by index 1 for the solvent and 2 for the dispersed phase $[43,44]$ :

$$
\kappa=\Phi \kappa_{2}+(1-\Phi) \kappa_{1} ; \quad \rho=\Phi \rho_{2}+(1-\Phi) \rho_{1}
$$

It is known that water has a different ultrasonic acoustic behavior in many aspects from other fluids. For example, below $74{ }^{\circ} \mathrm{C}$, the gradient of ultrasound propagation velocity in water is positive, while for most liquids it is negative. Another special property is the negative dilatation coefficient below $4{ }^{\circ} \mathrm{C}$. However, many experimental results are available for water, which facilitates studies based on this solvent. Moreover, the ultrasound speed in water strongly depends on the temperature.

This paper presents the experimental results of ultrasonic measurements on water (Wi), zinc contaminated water with $50 \mathrm{mg} / \mathrm{L}$ zinc ions (WZn) and water after decontamination (Wd). The time intervals between echoes make it possible to accurately determine the distance between the transducer face and the flat bottom surface of the used aluminum container. The obtained signals were processed using a specialized algorithm implemented in Matlab (Matlab2016). The modeling of the ultrasound wave effect on the analyzed samples was performed with an original model implemented in Comsol-Multiphysics finite elements program. The specialized program for temporal signal analysis 
allows determining the time differences between equivalent echoes in different fluids, with an accuracy of 1 ns. For all tested fluids, the reference was bi-distilled water. The small signals observed before the second and third echoes are signals of multiple reflections on the flat bottom of the aluminum container used for the fluids tested. These signals do not affect the results obtained in the signal interpretation program. Figure 9 shows the signals acquired for Wi, WZn and Wd. Figures 10-12 present the first, second and third echoes for the three studied samples, respectively.
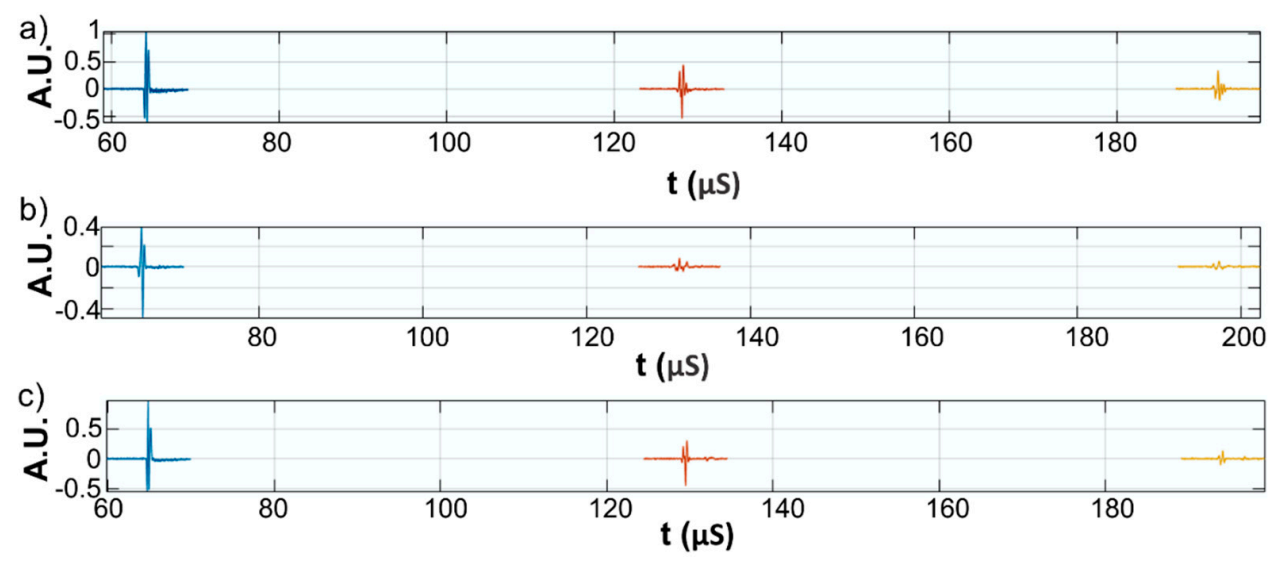

Figure 9. Acquired signals for: Wi (a); WZn (b); and Wd (c).

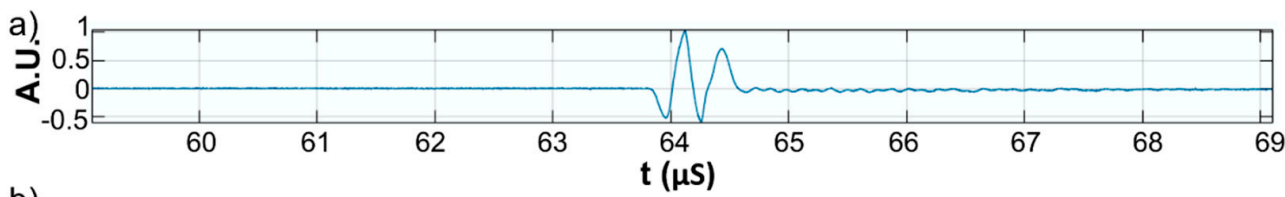

b) 0.4
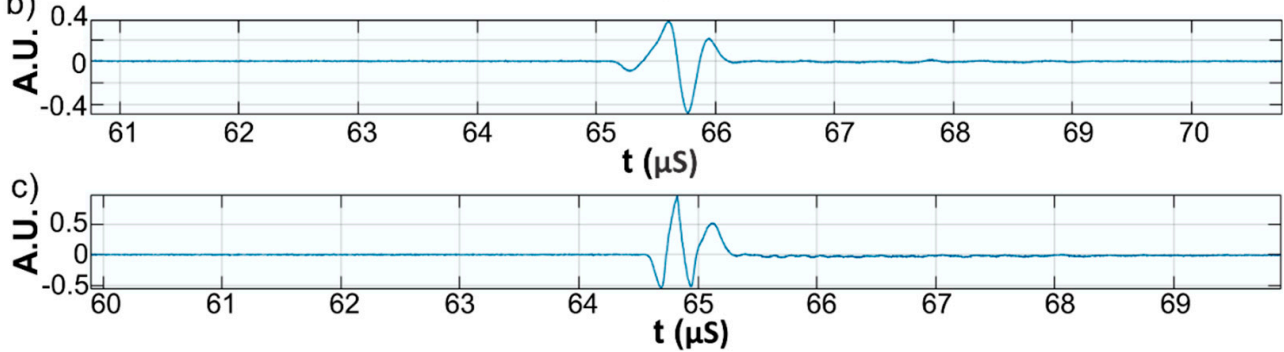

Figure 10. Zoomed first echo for: Wi (a); WZn (b); and Wd (c).
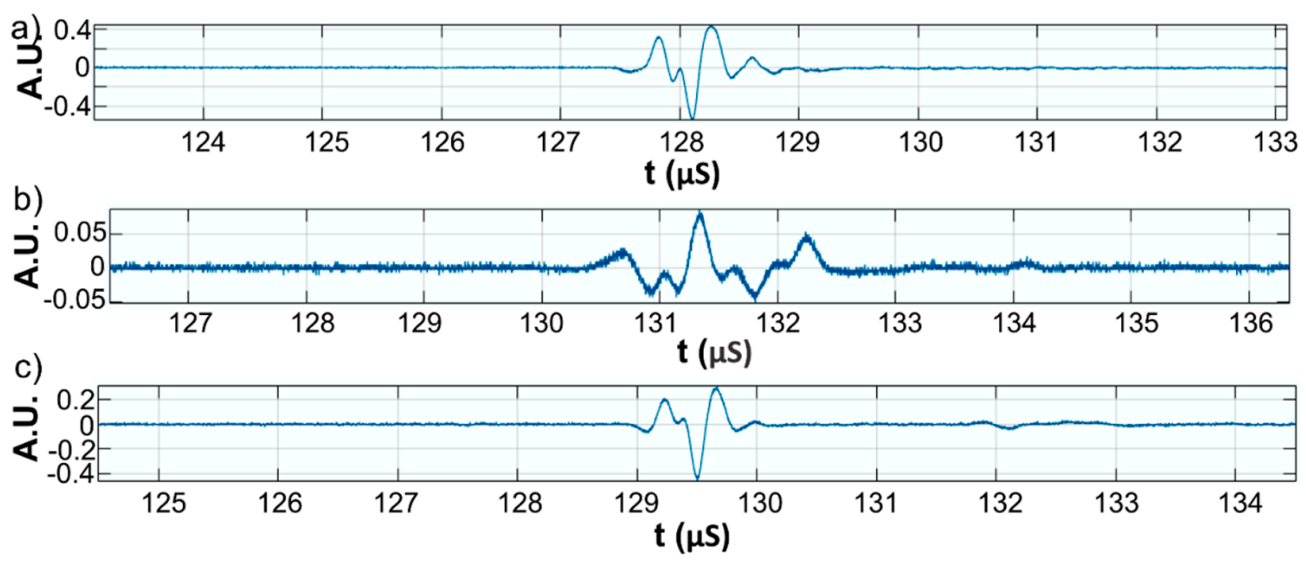

Figure 11. Zoomed second echo for: Wi (a); WZn (b); and Wd (c). 


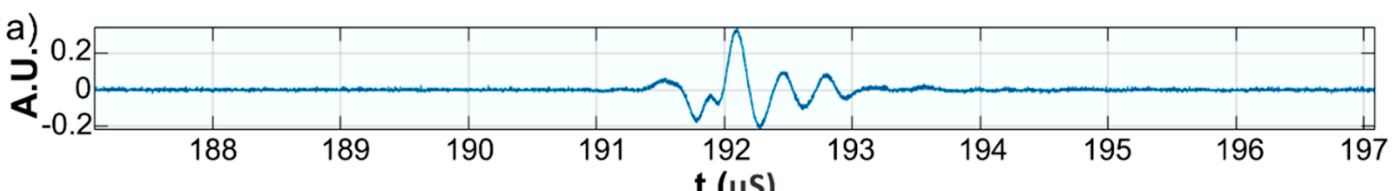

b)

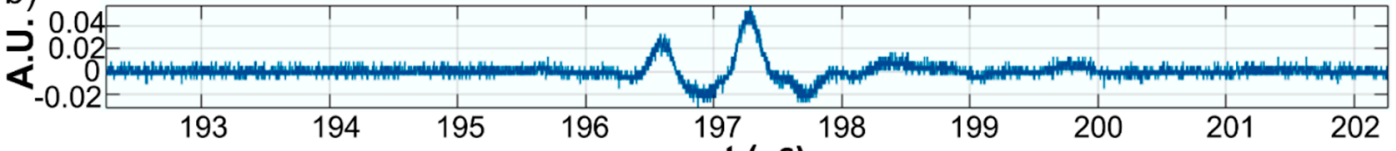

$t(\mu S)$

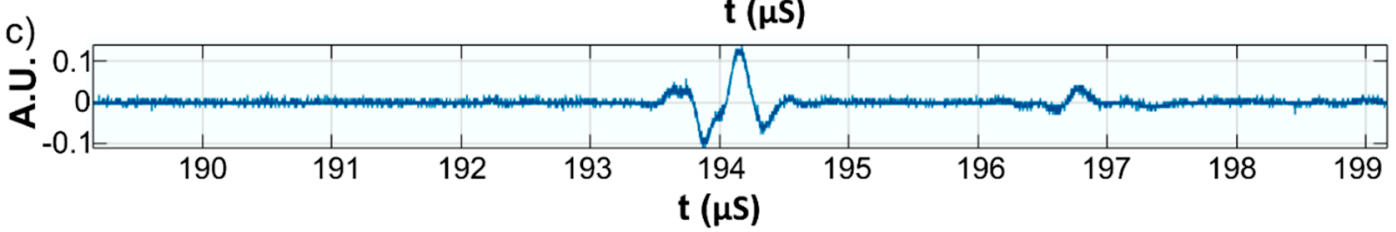

Figure 12. Zoomed third echo for: Wi (a); WZn (b); and Wd (c).

The time differences between each of the three echoes obtained for Wi e and WZn were obtained. Thus, in the case of the first echo recorded for Wi and WZn, there was a temporal difference of $1.67 \mu \mathrm{s}$. For the second echo, the temporal difference was $3.255 \mu \mathrm{s}$, which corresponds to a difference in equivalent signals of $1.628 \mu$ s. Similarly, for the third echo, the time difference to this echo was $5.17 \mu$, thus obtaining a temporal difference of $1.723 \mu$ s. Using the mean of these time differences and the distance traveled by the signals, the ultrasonic velocity was obtained by WZn $(1454.17 \pm 1.06 \mathrm{~m} / \mathrm{s})$ and an attenuation of $9.11055 \mathrm{~Np} / \mathrm{m}(1.04889 \mathrm{~dB} / \mathrm{m})$. In addition, the time differences between each of the three echoes obtained for $\mathrm{Wi}$ and $\mathrm{Wd}$ were obtained. Comparing the first recorded echo for bi-distilled water and $\mathrm{Wd}$ dispersion, a time difference of $0.703 \mu$ s was obtained. For the second echo, the time difference was $0.701 \mu \mathrm{s}$. Similarly, for the third echo, the temporal difference was $0.691 \mu$ s. Considering these temporal differences, ultrasonic velocity was obtained as $1476.02 \pm 0.15 \mathrm{~m} / \mathrm{s}$ for $\mathrm{Wd}$ and corresponding attenuation of $3.87419 \mathrm{~Np} / \mathrm{m}(0.446033 \mathrm{~dB} / \mathrm{m})$.

Figures 13-15 show overlapping of the three echoes obtained for Wi and WZn. The smaller signals, due to multiple reflections on the flat bottom of the aluminum container superposed over those of Wi (blue signals), can be seen. The almost disappearance of these low intensity signals in the case of WZn dispersions (orange signals) is determined by the increased ultrasonic signal attenuation for this medium. In overlapping these signals, the time delay is optimized for overlapping the signal modules, avoiding problems of phase jumps of the signal at the successive reflections on the aluminum bottom wall.
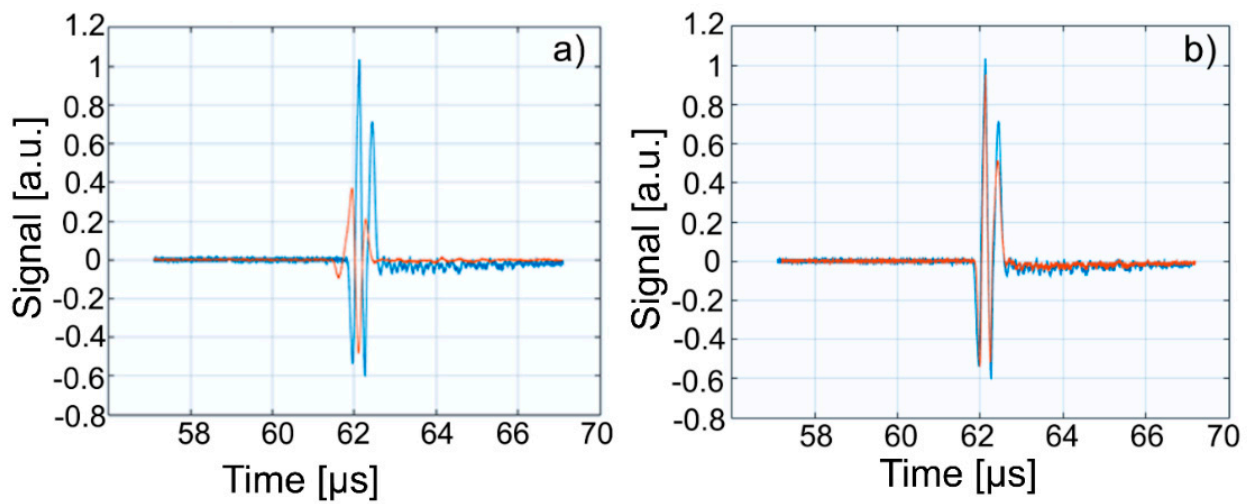

Figure 13. Overlapping of the first echo of Wi (blue) over signals from: WZn (a); and Wd (b) (orange).

The intensities of WZn signals are much weaker than those associated with Wi. This is due to the increased attenuation through the investigated dispersions. In the case of decontamination 
water $(\mathrm{Wd})$, the three signals resemble those of the Wi-associated signals, even if they are slightly attenuated. This behavior reveals that the amount of zinc in the Wd sample dropped significantly, since the decontaminated water has ultrasonic characteristics (velocity, signal aspect) closely resembling those of pure water. A great advantage of ultrasound measurements that were first used in such a study is that this method is reproducible and non-destructive. This method offers a quick analysis with low costs, as the consumption of resources such as water, electricity, etc. is low. On the other hand, the analyzed material (liquid or solid) is not damaged during the analysis and can be examined in the operative condition. The results obtained by ultrasound studies confirms the effectiveness of hydroxyapatite in the decontamination of zinc-polluted water.
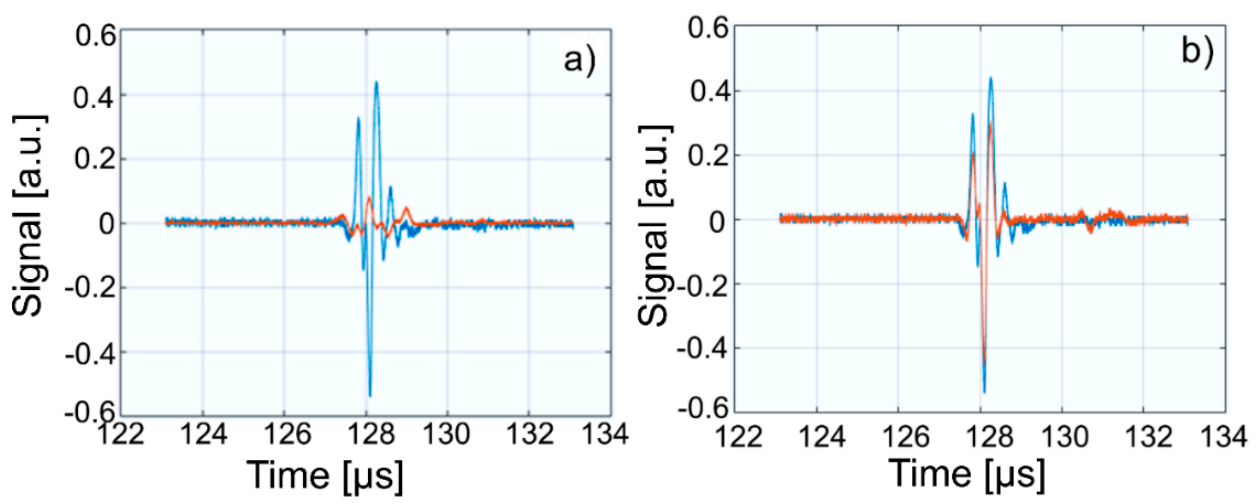

Figure 14. Overlapping of the second echo of Wi (blue) over signals from: WZn (a); and Wd (b) (orange).
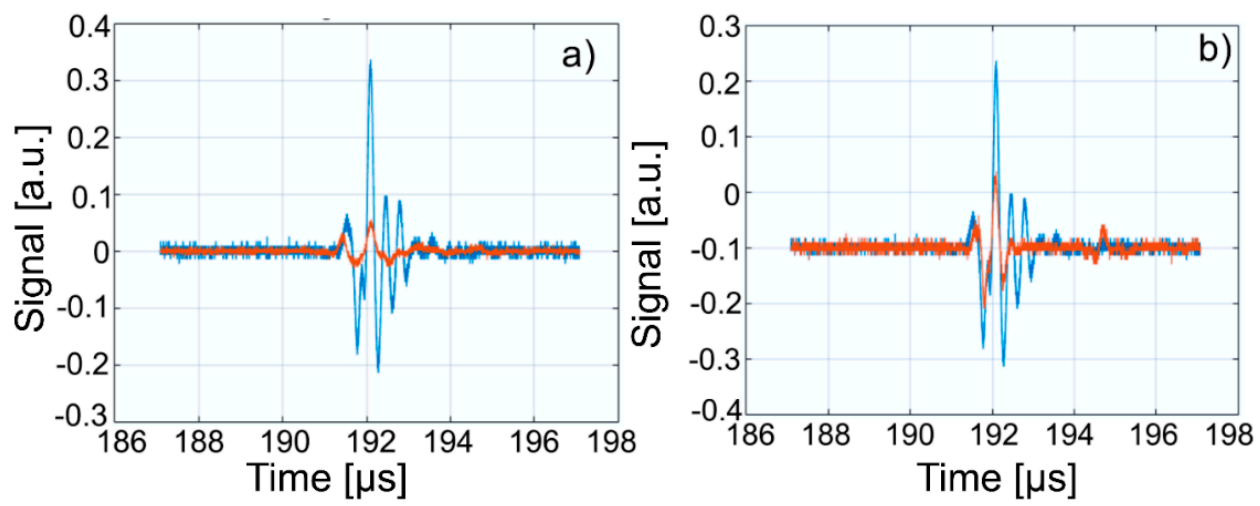

Figure 15. Overlapping of third echo of Wi (blue) over signals from: WZn (a); and Wd (b) (orange).

The present research is part of the recent concern about the use of hydroxyapatite as an adsorbent for metals in water. Due to its high affinity for divalent heavy metals ions, hydroxyapatite is a unique inorganic compound and has been used to remove various heavy metals such as nickel [56] lead [56-58], cadmium [59], cooper [60], zinc [8,61] and arsenic [62]. In their study, Ramesh et al. [4] reported that HAp had a greater affinity towards cooper ions compared to zinc ions, estimating a removal capacity of $125 \mathrm{mg}$ of $\mathrm{Cu} / \mathrm{g}$ and $30.3 \mathrm{mg}$ of $\mathrm{Zn} / \mathrm{g}$. Meanwhile, Chen et al. [62] highlighted that the sorption affinity of HAp for lead ions in single-metal sorption systems was significantly higher than for copper and cadmium ions. Regarding the adsorption capacity of zinc ions onto hydroxyapatite, studies have reported values in the range of $19.76-109.37 \mathrm{mg} / \mathrm{g}[63,64]$. The studies presented above are in good agreement with the results obtained in this research regarding the use of hydroxyapatite powders in the removal of zinc ions from contaminated aqueous solutions.

In conclusion, we could say that the hydroxyapatite has proven to be a good absorbent for zinc ions and could also be used for other pollutants. Furthermore, hydroxyapatite has additional benefits such as low costs and being easy to obtain. 


\section{Conclusions}

This study investigated the efficiency of hydroxyapatite obtained by an adapted coprecipitation method in the removal of zinc from aqueous solutions. During the process of removing zinc ions from aqueous solutions, zinc ions were introduced into the HAp lattice. After introducing zinc ions into the HAp lattice, a slight change in crystallinity and a decrease in particle size was observed. The adsorption of zinc ions from aqueous solutions was evidenced by XRD, SEM, and TEM. Hydroxyapatite has good affinity for $\mathrm{Zn}$. The effectiveness of hydroxyapatite in the decontamination of zinc-polluted water was confirmed for the first time by ultrasound studies. The decontaminated water has ultrasonic characteristics such as velocity and signal aspect closely resembling those of pure water. The sorption of $\mathrm{Zn}$ onto HAp was well characterized by the Langmuir and Freundlich models. The results revealed that the maximum adsorption capacity for the solid phase calculated from the linearized form of Langmuir equation, $\mathrm{q}_{\mathrm{m}}$, for $\mathrm{Zn}^{2+}$ was $57.504 \mathrm{mg} / \mathrm{g}$ and the Langmuir constant $\mathrm{K}_{\mathrm{L}}$ for the adsorption of $\mathrm{Zn}^{2+}$ was $0.052 \mathrm{~L} / \mathrm{mg}$. Furthermore, for the first time, the effectiveness of hydroxyapatite in the adsorption of zinc ions from contaminated solutions was highlighted by ultrasonic measurements. The results obtained from ultrasonic measurements were also in good agreement with those obtained from adsorption experiments.

The results obtained in the present study show that HAp nanopowders are good adsorbents for zinc ions and can therefore be considered for applications for removal of zinc ions from wastewater.

Author Contributions: Conceptualization, M.V.P. and D.P.; Formal analysis, S.L.I. and M.V.P.; Investigation, S.L.I., M.M.-H., R.G., M.V.P. and A.M.P.; Methodology, D.P.; Resources, M.M.-H. and R.G.; and Writing-original draft, M.V.P. and D.P.

Funding: This research was funded by [Unitatea Executiva pentru Finantarea Invatamantului Superior, a Cercetarii, Dezvoltarii si Inovarii (UEFISCDI)], grant number [PN-III-P1-1.2-PCCDI-2017-0629, Contract No. 43PCCDI/2018].

Acknowledgments: We thank A. Richard and A. Sauldubois from the "Centre de Microscopie Electronique" of University of Orléans for assistance in SEM and TEM data acquisition. This work was supported by the Romanian Ministry of Research and Innovation, UEFISCDI, through the projects PN-III-P1-1.2-PCCDI-2017-0134, Contract Nr. 23PCCDI/2018, PN-III-P1-1.2-PCCDI-2017-0629, Contract No. 43PCCDI/2018 and Contract No. T-IS 251801/04.05.2018.

Conflicts of Interest: The authors declare no conflict of interest.

\section{References}

1. Gangadhar, G.; Maheshwari, U.; Gupta, S. Application of nanomaterials for the removal of pollutants from effluent streams. Nanosci. Nanotech. Asia 2012, 2, 140-150. [CrossRef]

2. Crini, G. Recent developments in polysaccharide-based materials used as adsorbents in wastewater treatment. Prog. Polym. Sci. 2005, 30, 38-70. [CrossRef]

3. Yantasee, W.; Warner, C.L.; Sangvanich, T.; Addleman, R.S.; Carter, T.G.; Wiacek, R.J.; Fryxell, G.E.; Timchalk, C.; Warner, M.G. Removal of heavy metals from aqueous systems with thiol functionalized superparamagnetic nanoparticles. Environ. Sci. Technol. 2007, 41, 5114-5119. [CrossRef] [PubMed]

4. Ramesh, S.T.; Rameshbabu, N.; Gandhimathi, R.; Nidheesh, P.V.; Kumar, M.S. Kinetics and equilibrium studies for the removal of heavy metals in both single and binary systems using hydroxyapatite. Appl. Water. Sci. 2012, 2, 187-197. [CrossRef]

5. Fenga, Y.; Gonga, J.-L.; Zeng, G.-M.; Niu, Q.-Y.; Zhang, H.-Y.; Niu, C.-G.; Deng, J.-H.; Yan, M. Adsorption of $\mathrm{Cd}$ (II) and $\mathrm{Zn}$ (II) from aqueous solutions using magnetic hydroxyapatite nanoparticles as adsorbents. Chem. Eng. 2010, 162, 487-494. [CrossRef]

6. Mobasherpour, I.; Salahi, E.; Pazouki, M. Comparative of the removal of $\mathrm{Pb}^{2+}, \mathrm{Cd}^{2+}$ and $\mathrm{Ni}^{2+}$ by nano crystallite hydroxyapatite from aqueous solutions: Adsorption isotherm study. Arabia J. Chem. 2012, 5, 439-446. [CrossRef]

7. Malkoc, E. Ni (II) removal from aqueous solutions using cone biomass of Thuja orientalis. J. Hazard. Mater. 2006, B137, 899-908. [CrossRef] [PubMed] 
8. Skwarek, E. Adsorption of Zn on synthetic hydroxyapatite from aqueous solution. Sep. Sci. Technol. 2014, 49, 1654-1662. [CrossRef]

9. Crini, G. Non-conventional low-cost adsorbents for dye removal: A review. Bioresour. Technol. 2006, 97, 1061-1085. [CrossRef] [PubMed]

10. Pitcher, S.K.; Slade, R.C.T.; Ward, N.I. Heavy metal removal from motorway stormwater using zeolites. Sci. Total Environ. 2004, 334-335, 161-166. [CrossRef] [PubMed]

11. Bhattacharyya, K.G.; Gupta, S.S. Influence of acid activation on adsorption of Ni (II) and Cu (II) on kaolinite and montmorillonite: Kinetic and thermodynamic study. Chem. Eng. J. 2008, 136, 1-13. [CrossRef]

12. Thiebault, T.; Guégan, R.; Boussafir, M. Adsorption mechanisms of emerging micro-pollutants with a clay mineral: Case of tramadol and doxepine pharmaceutical products. J. Colloid Interface Sci. 2015, 453, 1-8. [CrossRef] [PubMed]

13. Guégan, R.; Giovanela, M.; Motelica-Heino, M. Nonionic organoclay: A 'swiss army knife' for the adsorption of micro-pollutants? J. Colloid Interface Sci. 2015, 437, 71-79. [CrossRef] [PubMed]

14. De Oliveira, T.; Guégan, R.; Thiebault, T.; Le Milbeau, C.; Muller, F.; Teixeira, T.; Giovanela, M.; Boussafir, M. Adsorption of diclofenac onto organoclays: Effects of surfactant and environmental ( $\mathrm{pH}$ and temperature) conditions. J. Hazard. Mater. 2017, 323, 558-566. [CrossRef] [PubMed]

15. De Oliveira, T.; Guégan, R. Coupled organoclay/micelle action for the adsorption of diclofenac. Environ. Sci. Technol. 2016, 50, 10209-10215. [CrossRef] [PubMed]

16. Simon, F.G.; Biermann, V.; Peplinski, B. Uranium removal from groundwater using hydroxyapatite. Appl. Geochem. 2008, 23, 2137-2145. [CrossRef]

17. Xu, Y.P.; Schwartz, F.W.; Traina, S.J. Sorption of $\mathrm{Zn}^{2+}$ and $\mathrm{Cd}^{2+}$ on hydroxyapatite surfaces. Environ. Sci. Technol. 1994, 28, 1472-1480. [CrossRef] [PubMed]

18. Srinivasan, M.; Ferraris, C.; White, T. Cadmium and lead ion capture with three dimensionally ordered macroporous hydroxyapatite. Environ. Sci. Technol. 2006, 40, 7054-7059. [CrossRef] [PubMed]

19. Babel, S.; Kurniawan, T.A. Low-cost adsorbents for heavy metals uptake from contaminated water: A review. J. Hazard. Mater. 2003, B97, 219-243. [CrossRef]

20. Derbyshire, F.; Jagtoyen, M.; Andrews, R.; Rao, A.; Martin-Gullon, I.; Grulke, E. Carbon materials in environmental applications. In Chemistry and Physics of Carbon; Radovic, L.R., Ed.; Marcel Dekker: New York, NY, USA, 2001; Volume 27, pp. 1-66.

21. Puanngam, M.; Unob, F. Preparation and use of chemically modified MCM-41 and silica gel as selective adsorbents for $\mathrm{Hg}$ (II) ions. J. Hazard. Mater. 2008, 154, 578-587. [CrossRef] [PubMed]

22. Hano, T.; Takanashi, H.; Hirata, M.; Urano, K.; Eto, S. Removal of phosphorus from wastewater by activated alumina adsorbent. Water. Sci. Technol. 1997, 35, 39-46. [CrossRef]

23. Tripathi, A.; Ranjan, M.R. Heavy metal removal from wastewater using low cost adsorbents. J. Biomed. Biodeg. 2015, 6, 1000315. [CrossRef]

24. Kurniawan, T.A.; Chan, Y.S.; Lo, W.L.; Babel, S. Comparisons of low-cost adsorbents for treating wastewaters laden with heavy metals. Sci. Total Environ. 2006, 366, 409-426. [CrossRef] [PubMed]

25. Pollard, S.J.T.; Fowler, G.D.; Sollars, C.J.; Perry, R. Low-cost adsorbents for waste and wastewater treatment: A review. Sci. Total Environ. 1992, 116, 31-52. [CrossRef]

26. Rorrer, G.L.; Way, J.D. Chitosan Beads to Remove Heavy Metal from Wastewater, Dalwoo-ChitoSan. May 2002. Available online: ftp:/ / dalwoo.com/chitosan/rorrer.html (accessed on 20 March 2018).

27. Virta, R. USGS Minerals Information, US Geological Survey Mineral Commodity Summary 2000. January 2001. Available online: ftp://minerals.usgs.gov/minerals/pubs/commodity/zeolites/zeomyb00.pdf (accessed on 21 May 2018).

28. Chen, X.; Wright, J.V.; Conca, J.L.; Peurrung, L.M. Effects of $\mathrm{pH}$ on heavy metal sorption on mineral apatite. Environ. Sci. Technol. 1997, 31, 624-631. [CrossRef]

29. Fuller, C.C.; Bargar, J.R.; Davis, J.A.; Piana, M.J. Mechanism of uranium interactions with hydroxyapatite: Implications for groundwater remediation. Environ. Sci. Technol. 2002, 36, 158-165. [CrossRef] [PubMed]

30. Krestou, A.; Xenidis, A.; Panias, D. Mechanism of aqueous uranium(VI) uptake by hydroxyapatite. Miner. Eng. 2004, 17, 373-381. [CrossRef]

31. Liang, W.; Zhan, L.; Piao, L.; Russel, C. Lead and copper removal from aqueous solutions by porous glass derived calcium hydroxyapatite. Mater. Sci. Eng. B 2011, 176, 1010-1014. [CrossRef] 
32. Dong, L.; Zhu, Z.; Qiu, Y.; Zhao, J. Removal of lead from aqueous solution by hydroxyapatite/magnetite composite adsorbent. Chem. Eng. J. 2010, 165, 827-834. [CrossRef]

33. Mobasherpour, I.; Salahi, E.; Pazouki, M. Removal of divalent cadmium cations by means of synthetic nano crystallite hydroxyapatite. Desalination 2011, 266, 142-148. [CrossRef]

34. Barrea, R.A.; Perez, C.A.; Ramos, A.Y.; Sanchez, H.J.; Grenon, M. Distribution and incorporation of Zn in biological calcium phosphates. X ray Spectrom. 2003, 32, 387-395. [CrossRef]

35. Canadian Water Quality Guidelines. Guidelines for Canadian Drinking Water Quality. 2004. Available online: http:/ / www.ec.gc.ca/CEQG-RCQE/English/Ceqg/Water/default.cfm (accessed on 15 March 2018).

36. World Health Organization. Guidelines for DrinkingWater Quality; WHO Library Catalogumg: Geneva, Switzerland, 1993; Volume 1, p. 52.

37. King, P.; Anuradha, K.; Lahari, S.B.; Kumar, Y.P.; Prasad, V.S.R.K. Biosorption of zinc from aqueous solution using Azadirachta indica bark: Equilibrium and kinetic studies. J. Hazard. Mater. 2008, 152, 324-329. [CrossRef] [PubMed]

38. McClements, D.J. Ultrasonic characterisation of emulsions and suspensions. Adv. Colloid Interface Sci. 1991, 37, 33-72. [CrossRef]

39. Dukhin, A.S.; Goetz, P.J. Characterization of Liquids, Nano-and Microparticulates, and Porous Bodies Using Ultrasound. In Studies in Interface Science, 2nd ed.; Elsevier: Amsterdam, The Netherlands, 2010; Volume 24, pp. 1-503.

40. Gomez Alvarez, T.E.; Segura, L.E.; Franco de Sarabia, E.R. Characterization of suspension of particles in water by an ultrasonic resonant cell. Ultrasonics 2002, 39, 715-727. [CrossRef]

41. Carroll, P.J.; Patterson, G.D. Rayleigh-Brillouin spectroscopy of simple viscoelastic liquids. J. Chem. Phys. 1984, 81, 1666-1675. [CrossRef]

42. Pandey, D.K.; Pandey, S. Ultrasonics: A technique of material characterization. In Acoustic Waves; Dissanayake, D.W., Ed.; IntechOpen: London, UK, 2010; p. 466.

43. Povey, M.J.W. Ultrasonic Techniques for Fluids Characterization; Academic Press: San Diego, CA, USA, 1997.

44. Povey, M.J.W. Acoustic methods for particle characterisation. Kona Powder Part. J. 2006, 24, $126-133$. [CrossRef]

45. Galaz, B.; Haïat, G.; Berti, R.; Taulier, N.; Amman, J.J.; Urbach, W. Experimental validation of a time domain simulation of high frequency ultrasonic propagation in a suspension of rigid particles. J. Acoust. Soc. Am. 2010, 127, 148-154. [CrossRef] [PubMed]

46. Zhou, W.; Su, M.X.; Cai, X.S. Advances in nanoparticle sizing in suspensions: Dynamic light scattering and ultrasonic attenuation spectroscopy. Kona Powder Part. J. 2017, 34, 168-182. [CrossRef]

47. Ciobanu, C.S.; Constantin, L.V.; Predoi, D. Structural and physical properties of antibacterial Ag-doped nano-hydroxyapatite synthesized at $100^{\circ} \mathrm{C}$. Nanoscale Res. Lett. 2011, 6, 613. [CrossRef] [PubMed]

48. Ciobanu, C.S.; Iconaru, S.L.; Popa, C.L.; Motelica-Heino, M.; Predoi, D. Evaluation of samarium doped hydroxyapatite, ceramics for medical application: Antimicrobial activity. J. Nanomater. 2015, 2015, 849216. [CrossRef]

49. Lajunen, L.H.J.; Peramaki, P. Spectrochemical Analysis by Atomic Absorption and Emission; Royal Society of Chemistry: Cambridge, MA, USA, 2004.

50. Cao, X.; Ma, L.Q.; Rhue, D.R.; Appel, C.S. Mechanisms of lead, copper, and zinc retention by phosphate rock. Environ. Pollut. 2004, 131, 435-444. [CrossRef] [PubMed]

51. Hayakawa, S.; Ando, K.; Tsuru, K.; Osaka, A. Structural characterization and protein adsorption property of hydroxyapatite particles modified with zinc ions. J. Am. Ceram. Soc. 2007, 90, 565-569. [CrossRef]

52. Mittal, A.; Mittal, J.; Malviya, A.; Kaur, D.; Gupta, V.K. Adsorption of hazardous dye crystal violet from wastewater by waste materials. J. Colloid Interface Sci. 2010, 343, 463-473. [CrossRef] [PubMed]

53. Langmuir, I. Chemical reactions at low pressures. J. Am. Chem. Soc. 1915, 27, 1139-1143. [CrossRef]

54. Freundlich, H. Uber die adsorption in losungen (Adsorption in solution). Z. Phys. Chem. 1906, 57, $384-470$.

55. Urick, R.J. The absorption of sound in suspensions of irregular particles. J. Acoust. Soc. Am. 1948, 20, $283-289$. [CrossRef]

56. Zamani, S.; Salahi, E.; Mobasherpour, I. Removal of nickel from aqueous solution by nano hydroxyapatite originated from persian gulf corals. Can. Chem. Trans. 2013, 1, 173-190.

57. Suzuki, T.; Ishigaki, K.; Miyake, M. Synthetic HAs as inorganic cation exchangers exchange characteristics of lead ions (Pb2?). J. Chem. Soc. Faraday Transm. 1984, 80, 3157-3165. [CrossRef] 
58. Mavropoulos, E.; Rossi, A.M.; Costa, A.M.; Perez, C.A.C.; Moreira, J.C.; Saldanha, M. Studies on the mechanisms of lead immobilization by hydroxyapatite. Environ. Sci. Technol. 2002, 36, 1625-1629. [CrossRef] [PubMed]

59. Lusvardi, G.; Malavasi, G.; Menabue, L.; Saladini, M. Removal of cadmium ion by means of synthetic hydroxyapatite. Waste Manag. 2002, 22, 853-857. [CrossRef]

60. Corami, A.; Mignardi, S.; Ferrini, V. Copper and zinc decontamination from single-and binary-metal solutions using hydroxyapatite. J. Hazard. Mater. 2007, 146, 164-170. [CrossRef] [PubMed]

61. Nakahira, A.; Okajima, T.; Honma, T.; Yoshioka, S.; Tanaka, I. Arsenic removal by hydroxyapatite-based ceramics. Chem. Lett. 2006, 35, 856-857. [CrossRef]

62. Chen, S.B.; Ma, Y.B.; Chen, L.; Xian, K. Adsorption of aqueous $\mathrm{Cd}^{2+}, \mathrm{Pb}^{2+}, \mathrm{Cu}^{2+}$ ions by nano-hydroxyapatite: Single-and multi-metal competitive adsorption study. Geochem. J. 2010, 44, 233-239. [CrossRef]

63. Lee, Y.J.; Elzinga, E.J.; Reeder, A.J. Sorption mechanisms of zinc on hydroxyapatite: Systematic uptake studies and EXAFS spectroscopy analysis. Environ. Sci. Technol. 2005, 39, 4042-4048. [CrossRef] [PubMed]

64. Pivarciova, L.; Rosskopfova, O.; Galambos, M.; Rajec, P. Adsorption behavior of Zn(II) ions on synthetic hydroxyapatite. Desalin. Water Treat. 2015, 55, 1825-1831. [CrossRef]

(C) 2018 by the authors. Licensee MDPI, Basel, Switzerland. This article is an open access article distributed under the terms and conditions of the Creative Commons Attribution (CC BY) license (http:/ / creativecommons.org/licenses/by/4.0/). 